\title{
RADARSAT の画像
}

竹内章司*

1995年11月, カナダは初めての地球観測衛星として 「RADARSAT」を打ち上げた。この衛星はその名の通 ク，合成開ロレーダ(SAR)のみを搭載する衛星であ る。レーダの波長は, ERS-1の SAR と同じCバンド $(5.3 \mathrm{GHz})$ であるが, 偏波は ERS-1のVVに対し $\mathrm{HH}$ となっている。また, 入射角, 分解能および観測 幅を目的に応じて変化させることが出来るという特徵 を持っている。

ここに紹介する画像は, 阪神地区と東京を撮影した RADARSATの画像である。阪神地区の画像はスタン
ダードモ一ド (分解能 $30 \mathrm{~m}$ ), 入射角 33.6 度, 東京の画像 はファインモード (分解能 $10 \mathrm{~m}$ ), 入射角 46.2 度でそれ ぞれ撮影されている。東京の画像では, レインボーブ リ) ジ (画像中央) や建設中の東京湾横断道路 (画像下 の長い直線) が明瞭に識別され, 将来の高分解能 SAR 画像の利用性に期待をいだかせる画像である。

RADARSATのデー夕は, 現在, (財)リモート・セ ンシング技術センターを通じて入手することが出来る。 データ諸元等については, 本誌の情報ルームを参照さ れたい。

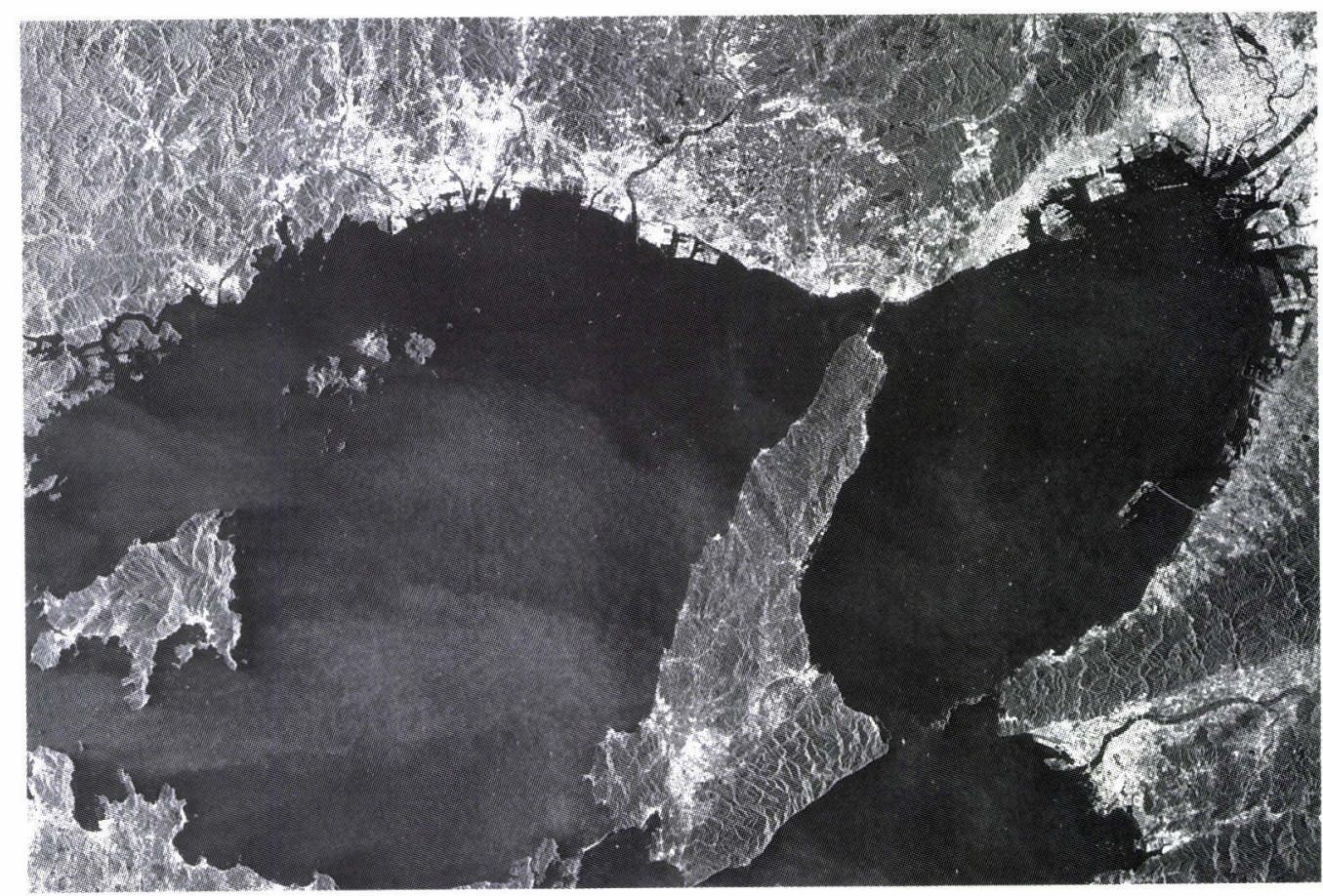

写真 1 阪神地区の RADARSAT 画像（1995年12月8日06：04） COPYRIGHT CSA 1995. RECEIVED BY CCRS AND PROCESSED AND DISTRIBUTED BY RSI

*(財)リモート・センシング技術センター

「写真測量とリモートセンシング」VOL. 35, NO. 4, 1996 


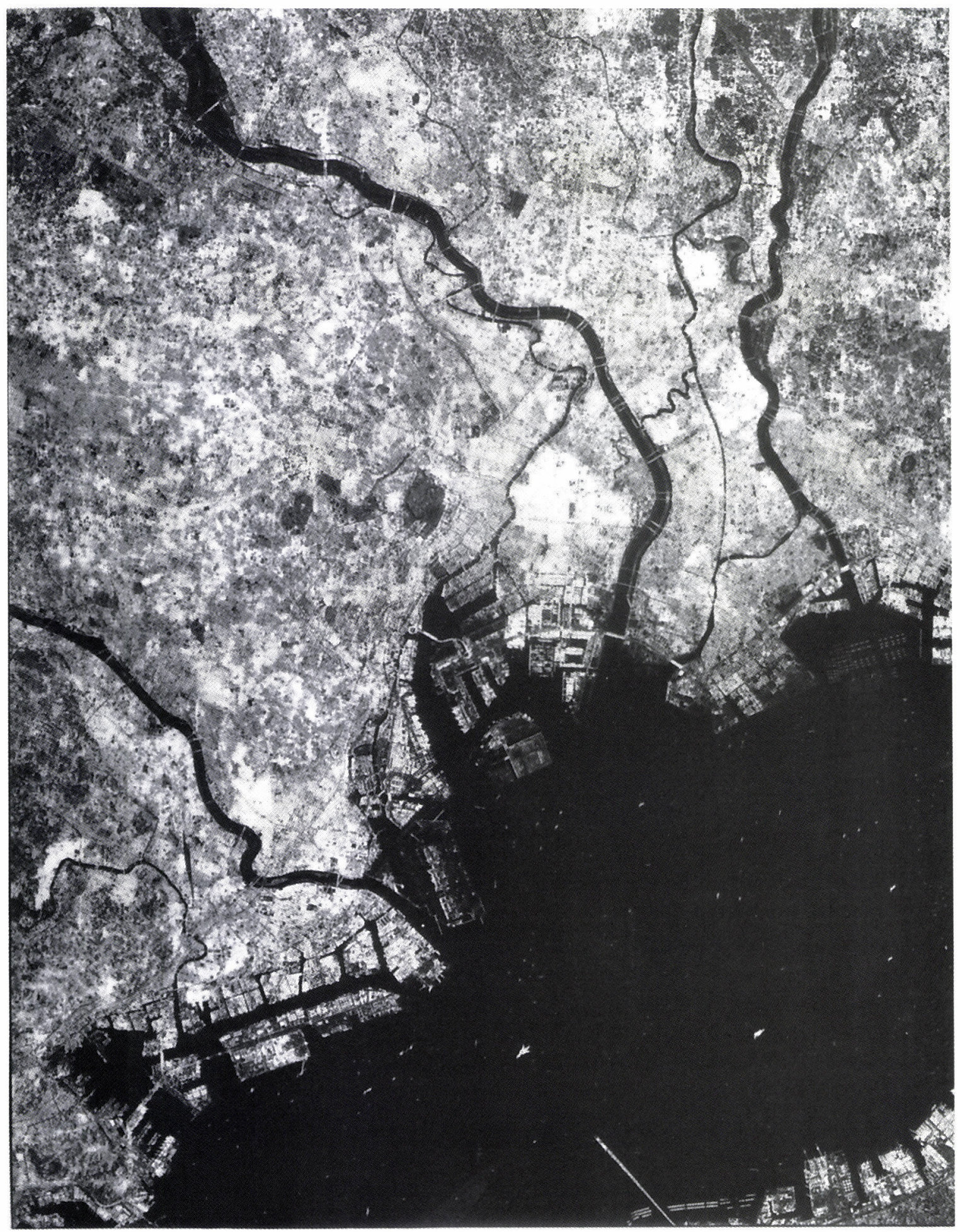

写真 2 東京の RADARSAT 画像（1995年12月31日17：47） COPYRIGHT CSA 1995. RECEIVED BY CCRS AND PROCESSED AND DISTRIBUTED BY RSI 